\title{
Effect of salt stress on the vegetative and reproductive growth of two genotypes of tomato (Solanum lycopersicum L.) plants in climatic condition of district Quetta, Balochistan
}

\author{
Bilal Ahmed Khan Kakar ${ }^{1 *}$, Saeed Ur Rehman Kakar ${ }^{1}$, Shahjahan Shabir \\ Ahmed Rana ${ }^{2}$, Saadullah Khan Leghari ${ }^{1}$, Aziz Ahmed ${ }^{3}$, Muhammad \\ Yousuf Tareen ${ }^{1}$ and Shams Ullah ${ }^{1}$ \\ 1. Department of Botany, University of Balochistan, Quetta-Pakistan \\ 2. Department of Biotechnology, Balochistan University of Information Technology, Engineering and Management \\ Sciences, Quetta-Pakistan \\ 3. Department of Economics, Balochistan University of Information Technology, Engineering and Management \\ Sciences, Quetta-Pakistan \\ *Corresponding author's email: bilalkakar68@gmail.com \\ Citation \\ Bilal Ahmed Khan Kakar, Saeed Ur Rehman Kakar, Shahjahan Shabir Ahmed Rana, Saadullah Khan Leghari, Aziz \\ Ahmed, Muhammad Yousuf Tareen and Shams Ullah. Effect of salt stress on the vegetative and reproductive \\ growth of two genotypes of tomato (Solanum lycopersicum L.) plants in climatic condition of district Quetta, \\ Balochistan. Pure and Applied Biology. Vol. 9, Issue 1, pp576-586. http://dx.doi.org/10.19045/bspab.2020.90063
}

\begin{tabular}{llll}
\hline \hline Received: 20/08/2019 & Revised: 03/12/2019 & Accepted: 07/12/2019 & Online First: 09/12/2019 \\
\hline
\end{tabular}

\section{Abstract}

The experiment conducted to evaluate the growth of two different genotypes of tomato plants under salt stress. The effect of sodium chloride measured using four different concentrations $(0.0 \mathrm{M}, 0.1 \mathrm{M}, 0.2 \mathrm{M}$, and $0.3 \mathrm{M})$ in a dose dependent manner. Seedling Height, Number of leave, Leave Area Index, Fresh weight, Dry weight (Biomass), Number of Flowers, Number of Fruits, Weight of Fruits and Maximum height of plant were measured in experiments. Results showed that tomato plants treated with a control group or less salt concentration presented better growth and survive for a longer period as compared to salt dominant groups. The results designates that salinity influences almost every parameter of plant growth, which concludes that salt stress has an antagonistic effect on plant growth.

Keywords: Biomass; Genotypes; Leaf area index; Plant growth; Salt stress

\section{Introduction}

The salt level in the soil now became the world major (related to surrounding conditions or the health of the Earth) trouble in agriculture. That restricts the farmingbased yield overall the world. Different (related to the chemicals in living things) and body-structure-related responses happened in plants by salinity [1].

Salinity produces hyper-osmotic stress and ionic disturbance; which make major cellular functions disable in a plant. Water 
availability increased, the respiratory rate changed mineral distribution, membrane instability, failure turgor pressure maintenance is few of the condition and tension prevailed at that time. To overcome these condition plants attempt to tolerate these stresses or go to the dormant stage [2]. When plants are exposed to a salt solution of $(200 \mathrm{mMNaCl})$ it makes the leaves and roots growth restricted to a certain degree [3].

When salt water is added to water, it's resulting in decline availability of nutrients that decrease the osmotic potential of root cells [4]. The high salt concentration affect key processes such as seed hampers flowering fruit set, as well as germination, seedling growth, and vigor, growth of plants. This ultimately results in a reduction of crop yield and quality [5].

It has been reported that an abundant amount of salinity is found in cultivated areas, mostly in the arid and semi-arid regions of the earth. Stunting of plants could also occur due to salinity condition [6, 7]. Salinity affected every aspect of a plant life cycle, included seed germination, vegetative growth, reproduction cycle of a plant, which caused low production and loss of economic yield [8]. In previous literature it has been investigated that increasing salinity in soil resulting in increased vegetative growth of tomato plant and also its yield [9]. Salt tolerance effectors and regulatory components gain importance near this juncture to salinity are modified and produce a unique variety of tomato that show more resistance to salt stress. These crops can be cultivated in saline condition and that will have significant importance for such purpose an extensive study is being taken place to invent a new tomato variety that shows more tolerance and resistance to salinity. For such design, an expression vector-like AtNHX1 is utilized, which is a gene that regulates $\mathrm{Na}+\mathrm{H}+$ antiport protein, an example of such process is the use of Arabidopsis thaliana to produce modified salinity tolerance plant [10].

Plants growth and development are influenced by salt stress, as it inhibits the absorption of essential nutrients and compounds, which is compulsory for plant growth, due to an accumulation of toxic ions like $\mathrm{Na}^{+}$and $\mathrm{Cl}^{-}$[11]. Different crops have been investigated to have different level of salt tolerance and if the salt level is increased in soil solution that might cause high osmotic potential and thus also increase its ion toxicity.

Primitive found that both antagonistic and synergistic interaction cause nutrient absorption problems and plant growth might be decreased when it's exposed to salt containing growth media because it decreases uptake of an essential nutrient [13].

\section{Materials and methods}

\section{Plants material and methods}

The experiment was conducted at the Botanical Garden University of Baluchistan. Two different genotypes (YAQUI and Prince F1) seedswere bought from the local market in Quetta. These varieties of tomato are often cultivated in Baluchistan.

\section{Sowing of seeds}

Seeds were sown in water for 24 hours before germination. 150 seeds of each genotype were implanted into the soil for germination. Seeds were irrigated every third day. Maximum of 14 and a minimum of 12 hours sunlight provided to seeds regularly. Healthy and flourishing seedling were selected for the experiment.

\section{Shifting of seedling to pots}

After 45 days of seeds germination the seedlings were shifted to pots. Size of a pot in diameter ranged from $12 \mathrm{~cm}$ to $16 \mathrm{~cm}$ in height. At that stage, the height of the seedling were measured using scale. The data collected from the seedling height shown no significant difference among groups. Four groups of each genotype were arranged in the experiment and each group treated with 
different levels of salt concentration $(\mathrm{T} 0=0.0 \mathrm{M}, \mathrm{T} 2=0.1 \mathrm{M}, \mathrm{T} 3=0.2, \mathrm{~T} 4=0.3 \mathrm{M})$ respectively. Three replicates of each treatment were used in the experiment. The pots were irrigated every day. Plants were exposed to natural light in between 12 to 14 hours each day.

\section{Parameters examine in the experiment}

Parameters of plant growth were measured at continuous and various stages of the experiment. As mention earlier that seedling height was measured at the time of transformation to pots and the fresh weight of plants was calculated just after harvesting.

The parameters measured were as under:

- Calculate the seedling height of the tomato plant

- Number of leaves

- Leaf area index of the tomato plant

- Number of flowers per plant

- Number of fruits per plant

- Weight of fruits

- Total fresh weight of the plant

- The total dry weight of plant (Biomass of plant)

- Maximum height of the plant in osmotic condition

\section{Statistical analysis}

For statistical interpretation, SPSS software was utilized. Two Way Analysis implemented to check variation within treatments and between varieties of tomato plant. The value of significance was considered as $\alpha<0.05$. or $\mathrm{p}<0.05$.Completely Randomized Design (CRD) was performed, with 3 replicationsand each pot contain one tomato seedling and one plant per replicate in group.

\section{Results}

\section{Seedling height}

Data analysis has shown that there is no significant difference $(p>0.05)$ in the seedling height of the plants. Both independent variable salt stress and genotypes (YAQUI, Prince F1) possess almost the same height when exposed to an identical environment. Table 1 displays the evidence that the p-value of salt stress among the treatments is 0.995 which is higher than 0.05 , thus it confirms there is no significant difference in seedling height among the treatments in both varieties. And if we concentrate on the column "Varieties salt stress" we find the same result no significant variation.

Table.1 Seedling height of tomato plants

\begin{tabular}{|c|c|c|c|c|c|}
\hline \multicolumn{7}{|c|}{ Tests of between-subjects effects } \\
\hline Dependent Variable & Biomass in gram & \multicolumn{4}{l|}{} \\
\hline Source & Type III Sum of Squares & df & Mean square & F & Sig. \\
\hline Corrected Model & $1.053^{\mathrm{a}}$ & 7 & 0.150 & 0.073 & 0.999 \\
\hline Intercept & 3405.784 & 1 & 3405.784 & 1642.661 & 0.000 \\
\hline Varieties & 0.050 & 1 & 0.050 & 0.024 & 0.878 \\
\hline Salt_stress & 0.151 & 3 & 0.050 & 0.024 & 0.995 \\
\hline Varieties * Salt_stress & 0.851 & 3 & 0.284 & 0.137 & 0.937 \\
\hline Error & 33.173 & 16 & 2.073 & & \\
\hline Total & 3440.010 & 24 & & & \\
\hline Corrected Total & 34.226 & 23 & & & \\
\hline \multicolumn{7}{|c|}{ a. R Squared =.031 (Adjusted R Squared = -.393) } \\
\hline
\end{tabular}


The estimated significant value displayed in table 1 is (0.995 and 0.937) for genotypes or within varieties respectively, which is greater than ( $p>0.05$ ) evidence that there is no significant variation in the seedling height of the tomato plant at that degree.

\section{Number of flowers}

Table 2 refines two different outcomes of two different independent variables (salt treatments and genotypes).

\section{Salt stress}

In table 2 significant value of salt stress is 0.000 which is less than 0.05 , which suggests that treatment among the groups show significant variation. Different level of salt treatments is adversely affecting the number of flowers. It has been reported that salinity affect flowering more than any other parameter of plant growth [14].
As we move from the control group (To) towards higher levels of salt concentration, we found that salt stress is decreasing the number of plants per plant that ultimately reducing the average of the flowers in each group. If we review in table 2 , we find a significant difference among the growth rate of tomato flowers, that result confers that salinity greatly reduces the flowering rate of the tomato plant. So we can presume that the salinity reduces the flower growth in the tomato plant.

\section{Number of flowers of tomato plants}

There is no sign of variation among the salt genotypes or varieties, which determines both of the varieties affected equally from salt stress in a completely randomized design (CRD) experiment (Table 2).

Table 2. Number of flowers of tomato plants

\begin{tabular}{|c|c|c|c|c|c|}
\hline \multicolumn{7}{|c|}{ Tests of between-subjects effects } \\
\hline Dependent variable & Biomass in gram & \multicolumn{4}{l|}{} \\
\hline Source & Type III sum of squares & df & Mean square & F & Sig. \\
\hline Corrected model & $131.833^{\text {a }}$ & 7 & 18.833 & 9.417 & 0.000 \\
\hline Intercept & 4108.167 & 1 & 4108.167 & 2054.083 & 0.000 \\
\hline Varieties & 0.000 & 1 & 0.000 & 0.000 & 1.000 \\
\hline Salt_stress & 129.833 & 3 & 43.278 & 21.639 & 0.000 \\
\hline Varieties * Salt_stress & 2.000 & 3 & 0.667 & 0.333 & 0.801 \\
\hline Error & 32.000 & 16 & 2.000 & & \\
\hline Total & 4272.000 & 24 & & & \\
\hline Corrected Total & 163.833 & 23 & & & \\
\hline \multicolumn{7}{|c|}{ a. R Squared } & .805 (Adjusted R squared = .719); (b) Varieties or genotypes \\
\hline
\end{tabular}

\section{Number of fruits}

Salinity inhibit fruit yield to a great extent, According to [15] Salinity reduces the growth rate of tomato (Lycopersicon esculentum Mill. cv. Daniela), primarily the number of fruits and also fruit size. Base on the statistical analysis of our data we observed the same outcome if we overview the data in table 3 , we find a significant difference in fruits number within treatments. Tomato fresh yield is significantly decreased by salinity [16]. Data in table 3 representing that there is a significant difference within the treatments as compared to the control group (To) all the other groups shown a reduction in fruit number.

The predicted significant value show in table 3 is (0.332) for genotypes or varieties, which 
is greater than $(\mathrm{p}>0.05)$ evidence that there is no significant difference in the number of fruits of the tomato plant. Confirmed that both varieties affected by salt stress at an equal concentration.

Table 3. Number of fruits of tomato plant

\begin{tabular}{|c|c|c|c|c|c|}
\hline Dependent variable & Number of fruits & \multicolumn{4}{|l|}{} \\
\hline Source & Type III sum of squares & df & Mean square & F & Sig. \\
\hline Corrected model & $20.625^{\mathrm{a}}$ & 7 & 2.946 & 7.857 & 0.000 \\
\hline Intercept & 108.375 & 1 & 108.375 & 289.000 & 0.000 \\
\hline Varieties & 0.375 & 1 & 0.375 & 1.000 & 0.332 \\
\hline Salt_stress & 20.125 & 3 & 6.708 & 17.889 & 0.000 \\
\hline Varieties * Salt_stress & 0.125 & 3 & 0.042 & 0.111 & 0.952 \\
\hline Error & 6.000 & 16 & 0.375 & & \\
\hline Total & 135.000 & 24 & & & \\
\hline Corrected Total & 26.625 & 23 & & & \\
\hline
\end{tabular}

\section{Fruits weight}

Analysis data mention in table. 4 shows that fruit weight is influenced by salt stress. The primitive research observed that salinity decreases fruit size by restricting water uptake through roots, which results in lower transport of water to the fruits. Another reference [17-19] affirmed that salinity caused a decrease in fruit weight leading to yield reduction. Tomato number doesn't affect by salt stress but it reduces fruit size that causes a reduction in yield of tomato in saline soil [20]. According to table .4, salt stress within treatments reveals a value of $(0.00<0.05)$ showing a significant difference in fruits weight, indicate that our data also support previous studies. Furthermore, table 4 also elaborates the variation within treatments.

If we review the variation in ratio among varieties. Table $4(0.032>0.05)$ suggesting that there is no significant difference in tomato weight between YAQUI and Prince F1varieties of tomato. Results clarified salt stress uniformly affected both varieties of a tomato plant.

Table 4. Fruits weight of tomato plants

\begin{tabular}{|c|c|c|c|c|c|}
\hline Dependent variable & Fruits weight & \multicolumn{3}{|l|}{} \\
\hline Source & Type III sum of squares & df & Mean square & F & Sig. \\
\hline Corrected Model & $12553.022^{\mathrm{a}}$ & 7 & 1793.289 & 6.781 & 0.001 \\
\hline Intercept & 60479.956 & 1 & 60479.956 & 228.682 & 0.000 \\
\hline Varieties & 1467.188 & 1 & 1467.188 & 5.548 & 0.032 \\
\hline Salt_stress & 8488.661 & 3 & 2829.554 & 10.699 & 0.000 \\
\hline Varieties * Salt_stress & 2597.174 & 3 & 865.725 & 3.273 & 0.049 \\
\hline Error & 4231.556 & 16 & 264.472 & & \\
\hline
\end{tabular}




\begin{tabular}{|c|c|c|c|c|c|}
\hline Total & 77264.535 & 24 & & & \\
\hline Corrected Total & 16784.579 & 23 & & & \\
\hline \multicolumn{5}{|c|}{ a. R Squared $=.748$ (Adjusted R Squared = .638) } \\
\hline
\end{tabular}

\section{Number of Leaves}

Salinity also reduces tomato leaves number in salt stress. According to previous study, increase in salt stress reduces tomato leaves number significantly [21]. Similar finding reported in previous literature that few plant varieties hold a negative association with $\mathrm{Na}+$ ions in leaves when exposed to salt stress [22]. In table 5 the number of leaves shows a significant variation in both varieties
(YAQUI and Prince F1) of a tomato plant. Result in table 5 also justified that leaves number were reduced by salinity. Data analysis provides a significant difference within treatments of salt stress however, shows no variation amongst varieties, suggesting that both YAQUI and Prince F1 varieties of the tomato plant are equally influenced by salt stress.

Table 5. Number of leaves of tomato plants

\begin{tabular}{|c|c|c|c|c|c|}
\hline Dependent variable & Number/leaves & \multicolumn{4}{|l|}{} \\
\hline Source & Type III sum of squares & df & Mean square & F & Sig. \\
\hline Corrected Model & $1108.958^{\mathrm{a}}$ & 7 & 158.423 & 12.425 & 0.000 \\
\hline Intercept & 32782.042 & 1 & 32782.042 & 2571.141 & 0.000 \\
\hline Varieties & 9.375 & 1 & 9.375 & 0.735 & 0.404 \\
\hline Salt_stress & 1091.125 & 3 & 363.708 & 28.526 & 0.000 \\
\hline Varieties * & 8.458 & 3 & 2.819 & 0.221 & 0.880 \\
\hline Salt_stress & 204.000 & 16 & 12.750 & & \\
\hline Error & 34095.000 & 24 & & & \\
\hline Total & 1312.958 & 23 & & \\
\hline Corrected Total & \multicolumn{7}{|c|}{ a. R Squared =.845 (Adjusted R Squared =.777) } \\
\hline \multicolumn{7}{|l|}{} \\
\hline
\end{tabular}

\section{Leaf area index}

Tomato plant leaf area index is greatly influenced by salt stress. Table 6 express a value of $(0.000<0.05)$ showing that the leaf area index of tomato plants is significantly affected by salinity. Common findings registered salt stress of 40 and $60 \mathrm{mM}$ decreases the leaf area index of the tomato plant [23]. Similar result found in previous literature, increasing salt stress to a level of (EC range: $2.5-6 \mathrm{dS} \mathrm{m}-1$ ) produce a reduction in leaf area of tomato (Lycopersicon esculentum Mill) plant [30]. Common results display in Table.6, tomato plant leaf area index continuously decreases as the salt concentration increases.

Table 6 display value of $(0.685>0.05)$ elaborate that salinity doesn't show a significant difference within varieties. Both YAQUI and Prince F1 varieties of tomato plants are affected uniformly by salt stress in completely randomized designed (CRD) experiment.

\section{Total fresh weight of plants}

Plant weight was calculated in gram $(\mathrm{g})$ with electrical balance. Result display in table 7 
explains significant variation within treatments. In Table.7 the significant value or p-value for salt stress is $(0.004)$ that verified there is a significant difference within the treatments. Similar results were found that tomato (Solanum lycopersicum L.) root fresh weight decreased upto $30 \%$ when exposed to $(100 \mathrm{mM} \mathrm{NaCl})$ of salt stress [24]. As mentioned in table 7 that increasing salinity reduce total fresh weight of tomato plant. If we review the value of varieties Colum (0.721) produce greater result than $\mathrm{p}$-value (0.05), we find no significant difference among the varieties. Which illuminated that salinity affects both varieties uniformly at the identical condition.

Table 6. Leaf area index of tomato plants

\begin{tabular}{|c|c|c|c|c|c|}
\hline Dependent variable & Leaf area index & & & & \\
\hline $\begin{array}{l}\text { Source } \\
\end{array}$ & Type III sum of squares & df & Mean square & $\mathbf{F}$ & Sig. \\
\hline Corrected Model & $87.201^{\mathrm{a}}$ & 7 & 12.457 & 11.172 & 0.000 \\
\hline Intercept & 964.694 & 1 & 964.694 & 865.139 & 0.000 \\
\hline Varieties & 0.191 & 1 & 0.191 & 0.171 & 0.685 \\
\hline Salt_stress & 85.071 & 3 & 28.357 & 25.430 & 0.000 \\
\hline Varieties $*$ Salt_stress & 1.940 & 3 & 0.647 & 0.580 & 0.637 \\
\hline Error & 17.841 & 16 & 1.115 & & \\
\hline Total & 1069.737 & 24 & & & \\
\hline Corrected Total & 105.042 & 23 & & & \\
\hline \multicolumn{6}{|c|}{ a. $\mathrm{R}$ Squared $=.830($ Adjusted R Squared $=.756)$} \\
\hline
\end{tabular}

Table 7. Total fresh weight of plants

\begin{tabular}{|c|c|c|c|c|c|}
\hline \multicolumn{7}{|c|}{ Tests of between-subjects effects } \\
\hline Dependent variable & Total fresh weight of plants & \multicolumn{1}{l|}{} \\
\hline Source & Type III sum of squares & df & Mean square & F & Sig. \\
\hline Corrected Model & $1982.110^{\mathrm{a}}$ & 7 & 283.159 & 14.210 & 0.000 \\
\hline Intercept & 15545.369 & 1 & 15545.369 & 780.134 & 0.000 \\
\hline Varieties & 1546.418 & 1 & 1546.418 & 77.606 & 0.000 \\
\hline Salt_stress & 408.785 & 3 & 136.262 & 6.838 & 0.004 \\
\hline Varieties * Salt_stress & 26.907 & 3 & 8.969 & 0.450 & 0.721 \\
\hline Error & 318.825 & 16 & 19.927 & & \\
\hline Total & 17846.303 & 24 & & & \\
\hline Corrected Total & 2300.934 & 23 & & \\
\hline \multicolumn{7}{|c|}{ a. R Squared = .861 (Adjusted R Squared = .801) } \\
\hline
\end{tabular}

\section{Biomass}

Just after harvesting plants were reserved in bags to ensure no loss of data. Later biomass of each plant of both varieties (YAQUI and Prince F1) was collected. To obtain biomass plants were incubated in the oven at 65 
centigrade for 15 minutes to remove the water content from plants. Later every plant weight was calculated with an electrical balance in gram $(\mathrm{g})$.

Demonstrated data shown in table. 8 strongly suggest that there is a significant difference within the groups, the outcome of data analyzed display a result of 0.03 which indicates the chance of similarity among the treatments in each variety is only $3 \%$. If we examine the result in Table 3, we can see the reduction of biomass when the salt treatments are increased. Confirms that salinity adversely affects the dry weight of the tomato plant. Previous study also found that salinity reduce biomass of tomato plant. Plant like L. peruvianum and L. pennellii when exposed to a different level of salt stress produce a decrease in root biomass [25].

Table 8 also elaborate that there is no significant variation in the second independent variable of the experiment, which is in between genotypes of tomato, Table. 8 shows a value of 0,469 greater than 0.05 . Verifying that salt stress affects the biomass of both varieties uniformly.

Based on our experimental data we can estimate there is a reduction in tomato biomass with an increase in salt levels both in YAQUI and Prince F1 varieties. But there is no significant difference between the genotypes which justified that the salt treatments influence both varieties (YAQUI and Prince F1) correspondingly.

Table 8. Total biomass of tomato plants

\begin{tabular}{|c|c|c|c|c|c|}
\hline \multicolumn{7}{|c|}{ Tests of between-subjects effects } \\
\hline Dependent variable & Biomass in gram & \multicolumn{1}{l|}{} \\
\hline Source & Type III sum of squares & df & Mean square & F & Sig. \\
\hline Corrected Model & $41.700^{\mathrm{a}}$ & 7 & 5.957 & 16.966 & 0.000 \\
\hline Intercept & 259.647 & 1 & 259.647 & 739.454 & 0.000 \\
\hline Varieties & 33.182 & 1 & 33.182 & 94.500 & 0.000 \\
\hline Salt_stress & 7.583 & 3 & 2.528 & 7.199 & 0.003 \\
\hline Varieties* Salt_stress & 0.935 & 3 & 0.312 & 0.888 & 0.469 \\
\hline Error & 5.618 & 16 & 0.351 & & \\
\hline Total & 306.965 & 24 & & & \\
\hline Corrected Total & 47.319 & 23 & & \\
\hline
\end{tabular}

\section{Maximum height of plants}

The height of the plants was calculated at the time of harvesting. The measuring scale was used to calculate the height of plants in centimeter $(\mathrm{cm})$. Plant height was measured from the base of the root to the uppermost leaf apex

Table 9 provides contrasting results for two independent variables salt stress and genotypes (varieties). If we examine the value of salt stress for height, within treatments of both varieties, we observed a significant difference among the value. Table. 9 provides a $\mathrm{p}$-value of 0.00 which is less than 0.05 , verify that there is adequate variation in height of plants among the treatments in both varieties. The result display in Table. 8 further elaborates the variation of salt stress within treatments. Table 9 further illustrate that there is no 
significant difference found among the varieties of plants. The significant value is $0.23>0.05$ proves that there is no significant difference between varieties. Which mean that both varieties Rome and Prince Flaffected identically to salt stress in a given condition.

Table 9. Maximum height of tomato plants on harvesting

\begin{tabular}{|c|c|c|c|c|c|}
\hline \multicolumn{7}{|c|}{ Tests of between-subjects effects } \\
\hline Dependent variable & Biomass in gram & \multicolumn{1}{l|}{} \\
\hline Source & Type III sum of squares & df & Mean square & F & Sig. \\
\hline Corrected Model & $1208.289^{\mathrm{a}}$ & 7 & 172.613 & 13.530 & 0.000 \\
\hline Intercept & 53510.648 & 1 & 53510.648 & 4194.344 & 0.000 \\
\hline Varieties & 4.815 & 1 & 4.815 & 0.377 & 0.548 \\
\hline Salt_stress & 1043.904 & 3 & 347.968 & 27.275 & 0.000 \\
\hline Varieties * Salt_stress & 159.570 & 3 & 53.190 & 4.169 & 0.023 \\
\hline Error & 204.125 & 16 & 12.758 & & \\
\hline Total & 54923.063 & 24 & & & \\
\hline Corrected Total & 1412.414 & 23 & & \\
\hline \multicolumn{7}{|c|}{ a. R Squared = .855 (Adjusted R Squared = .792) } \\
\hline
\end{tabular}

\section{Discussion}

The effect of salt stress on the growth parameters of tomato was investigated. Salinity not only influenced the fruits yield of tomato plants but all other parameters. It is noticed in (Table 1) the seedling height shows no significant difference in both varieties. So without salt treatments at the seedling stage, there is no evidence of variation between groups and varieties. The number of flowers is reduced as the salt stress increased within treatments or groups; display in table 2. Number of fruits decreases as the salt stress increases with in treatments (Table 2). Primitive investigations also presented common output. Tomato varieties Tainan ASVEG No. 19, Hualien ASVEG No. 21 and Taiwan Seed ASVEG No. 22, when treated to $150 \mathrm{mM}$ solution of salt stress, show a significant reduction in of fruits numbers per plant [26]. Salinity restrict fruits weight as display in table 3. Previous literature also justifies our findings. Table 6 displays a significant difference of leaf area index. When salt stress applied to two different genotypes of the tomato plant (Lycopersicon esculentum). Daniela F1 and Moneymaker) tomato leaf area decreased [27].

Toxic ions like $\mathrm{Na}+$ and $\mathrm{Cl}$ - also negatively influenced the stomatal conductance alternatively affected the leaf area index and root growth of a plant, which shown in table 6 . A related outcome was noticed that the salt treatment (200 $\mathrm{mMNaCl})$ affected and reduce the growth rate of both leave and root [3].

Roots are directly associated with growth media which contain toxic salt ions (sodium and chloride ions), that prevent the long term root growth alternatively that affect the biomass composition like leave weight [28]. Under the saline condition, $\mathrm{CO} 2$ assimilation of the plant reduced, as $\mathrm{CO} 2$ is a major energy source for growth and development, therefore, it ultimately results 
in root growth reduction [29]. The reduction in root length caused the decrease in biomass which is commonly observed under salt stress [30]. Numerous research found that salt stress to plant roots result in a decline of plant growth, ultimately caused smaller fruit size and decrease yield [31, 32].

\section{Conclusion}

Based on the above results and pieces of evidence we justified that salt stress adversely influenced the tomato plant growth rate and development as well as a physiological process like photosynthesis rate and all parameters of the experiment including, number of fruits, fruit weight, leaves number, leaf area index, fresh weight, dry weight and maximum height of tomato plant at harvesting. Previous study also approves that salt stress affects plant growth, root and number of leaves. It was noticed that fresh and dry weights of plants increased with an increase in salinity in Salicorniarubra while the optimal growth occurred at 200 $\mathrm{mMNaCl}$ and the growth was inhibited with a further increase in salinity. Salinity stress significantly reduced the root, stem and leaf dry matter and leaf area compared with the control treatment due to direct effects of ion toxicity or indirect effects of saline ions that cause soil/plant osmotic imbalance. Because salt stress affects the photosynthesis rate and $\mathrm{CO} 2$ intake, so it is proof that not only tomato plants but almost every plant species are affected by salinity.

\section{Authors' contributions}

Conceived and designed the experiments: SR Kakar, SSA Rana \& BAK Kakar, Performed the experiments: SS Rana \& B Kakar, Analyzed the data: SS Rana \& Aziz Ahmed, Contributed materials/ analysis/ tools: SK Leghari, MY Tareen \& S Ullah, Wrote the paper: SSA Rana \& BAK Kakar.

\section{Reference}

1. Nemoto $\mathrm{Y} \&$ Sasakuma $\mathrm{T}$ (2002). Differential stress responses of early saltstress responding genes in common wheat. Phytochem 61(2): 129-133.
2. Cuartero J, Bolarin MC, Asins MJ \& Moreno $\mathrm{V}$ (2006). Increasing salt tolerance in the tomato. J of Exper Bot 57(5): 1045-1058.

3. Cavalcanti FR, Lima, JPMS, Ferreira-Silva, SL, Viégas, R A, \& Silveira, JAG (2007). Roots and leaves display contrasting oxidative response during salt stress and recovery in cowpea. $J$ of Plant Physiol 164(5): 591-600.

4. Sairam RK, Rao KV \& Srivastava GC (2002). Differential response of wheat genotypes to long term salinity stress in relation to oxidative stress, antioxidant activity and osmolyte concentration. Plant Sci 163(5): 1037-1046.

5. Sairam RK \& Tyagi A (2004). Physiology and molecular biology of salinity stress tolerance plants. Current Sci 407-421.

6. Madidi SAID, El Baroudi, BRAHIM \& Aameur FB (2004). Effects of salinity on germination and early growth of barley (Hordeum vulgare L.) cultivars. Inter $J$ of Agric \& Biol 6(5): 767-770.

7. Hernandez JA, Olmos E, Corpas FJ, Sevilla F \& Del Rio LA (1995). Salt-induced oxidative stress in chloroplasts of pea plants. Plant Sci 105(2) 151-167.

8. Jones RA (1986). High salt tolerance potential in Lycopersicon species during germination. Euphytica 35(2): 575-582.

9. Bolarin MC, Perez-Alfocea F, Cano EA, Estan, MT \& Caro M (1993). Growth, fruit yield, and ion concentration in tomato genotypes after pre-and post-emergence salt treatments. $J$ of the American Soc for Hortic Sci 118(5): 655-660.

10. Zhang HX \& Blumwald E (2001). Transgenic salt-tolerant tomato plants accumulate salt in foliage but not in fruit. Nat Biotechnol 19(8): 765.

11. Sabir P \& Ashraf M (2008). Inter-cultivar variation for salt tolerance in proso millet (Panicum miliaceum L.) at the germination stage. Pak J Bot 40(2): 677-682.

12. Greenway H (1973). Salinity, plant growth, and metabolism. J of Australian Inst Agr Sci.

13. Feigin A (1985). Fertilization management of crops irrigated with saline water. In Biosalinity in Action: Bioproduction with Saline Water (pp 285-299). Springer, Dordrecht. 
14. Strogonov BP (1964). Physiological basis of salt tolerance of plants (as affected by various types of salinity). Physiological basis of salt tolerance of plants (as affected by various types of salinity).

15. Del Amor FM, Martinez V \& Cerda A (2001). Salt tolerance of tomato plants as affected by stage of plant development. Hortic Sci 36(7): 1260-1263.

16. Magán JJ, Gallardo M, Thompson RB \& Lorenzo P (2008). Effects of salinity on fruit yield and quality of tomato grown in soil-less culture in greenhouses in Mediterranean climatic conditions. Agric Water Manag 95(9): 1041-1055.

17. Sakamoto $Y$, Watanabe $S$, Nakashima $T$ \& Okano K (1999). Effects of salinity at two ripening stages on the fruit quality of singletruss tomato grown in hydroponics. The $J$ of Hortic Sci and Biotechnol 74(6): 690-693.

18. Adams P (1991). Effects of increasing the salinity of the nutrient solution with major nutrients or sodium chloride on the yield, quality and composition of tomatoes grown in rockwool. J of Hortic Sci 66(2): 201-207.

19. Cuartero J \& Fernández-Muñoz R (1998). Tomato and salinity. Scientia Hortic 78(14): 83-125.

20. Eltez RZ, Tüzel Y, Gül A, Tüzel IH \& Duyar H (2000, November). Effects of different EC levels of nutrient solution on greenhouse tomato growing. In International Symposium on Techniques to Control Salination for Horticultural Productivity 573 (pp 443-448).

21. Adams P (1990). Effects of watering on the yield, Quality and composition of tomatoes grown in bags of peat. J Hortic Sci 65: 667674.

22. Essa TA (2002). Effect of salinity stress on growth and nutrient composition of three soybean (Glycine max L. Merrill) cultivars. $J$ of Agro and Crop Sci 188(2): 86-93

23. Hajiaghaei-Kamrani M, Khoshvaghti H \& Hosseinniya H (2013). Effects of salinity and hydroponic growth media on growth parameters in tomato (Lycopersicon esculentum Mill.). Inter J of Agro and Plant Prod 4(10): 2694-2698.

24. Albacete A, Ghanem ME, Martinez-Andujar C, Acosta M and Sanchez-Bravo J (2008). Hormonal changes in relation to biomass partitioning and shoot growth impairment in salinized tomato (Solanum lycopersicum L.) plants. J Exp Bot 59: 4119-4131

25. Maggio A , De Pascale S, Angelino G, Ruggiero C \& Barbieri G (2004). Physiological response of tomato to saline irrigation in long-term salinized soils. Euro $J$ of Agron 21(2): 149-159.

26. Liu FY, Li KT, \& Yang WJ (2014). Differential responses to short-term salinity stress of heat-tolerant cherry tomato cultivars grown at high temperatures. Hortic, Environ, and Biotechnol 55(2): 79-90.

27. Romero-Aranda R, Soria $\mathrm{T} \&$ Cuartero $\mathrm{J}$ (2001). Tomato plant-water uptake and plant-water relationships under saline growth conditions. Plant Sci 160(2): 265-272.

28. Tyerman SD \& Skerrett IM (1998). Root ion channels and salinity. Scientia Hortic 78(14): $175-235$.

29. Syvertsen JP, Lee LS \& Grosser JW (2000). Limitations on growth and net gas exchange of diploid and tetraploid Citrus rootstock cultivars grown at elevated $\mathrm{CO} 2 . J$ of the American Soc for Hort Sci 125(2): 228-234.

30. Vasquez EA, Glenn EP, Guntenspergen GR, Brown JJ \& Nelson SG (2006). Salt tolerance and osmotic adjustment of Spartina alterniflora (Poaceae) and the invasive $M$ haplotype of Phragmites australis (Poaceae) along a salinity gradient. American $J$ of $B o t$ 93(12): 1784-1790.

31. Mohammad M, Shibli R, Ajlouni M \& Nimri L (1998). Tomato root and shoot responses to salt stress under different levels of phosphorus nutrition. $J$ of Plant Nutr 21(8): 1667-1680

32. Scholberg JMS \& Locascio SJ (1999). Growth response of snap bean and tomato as affected by salinity and irrigation method. Hort Sci 34(2): 259-264. 